120) Toor, H. L.: A. I. Ch. E. Journal, 8, 70 (1962)

121) Van de Vusse, J.G.: Chem. Eng. Sci., 21, 631 (1966)

122) Van de Vusse, J.G.: ibid., 21, 645 (1966)

123) Van Krevelen, D. W. and P. J. Hoftijzer: Rec. Trav. Chim., 67, 563 (1948)
124) Yagi, S. and H. Inoue: Chem. Eng. Sci, 17, 411 (1962)

125) Yamaguchi, I., T., Oishi, N. Hashimoto and S. Nagata : Mem. Fac. Eng., Kyoto Univ., 27, 118 (1965)

126）吉田文武, 大竹云雄, 中尾勝实：化学工学, 30, 460 (1966)

\title{
XXX-4。吸收装是と吸収プロセ ス*
}

鈴 木 昭**

\section{まえがき}

吸収操作は広く化学工業の分野に打いて，硫酸，硝 酸，塩酸の製造、アンモニア，メタノール，オキッ合成 ガス等の精製，都市ガス，水素ガス，製油所廃ガスの精 製，各種がスから有効成分の回収等に使われている。装 置規模の大型化, 公害問題と関連してょり経済性のある しかも信頼性の高い装置およびプロセスの選定が重要と なる。本稿では最近の文献に発表されている工業的吸収 装置と呂収ブロセスに関する設計資料，設計手法，選定 の基準および概要について䂏介する。

\section{1. 吸収装}

吸収理論の展開，吸収機構の理解，装置設計の基礎資 料などに関する実験が活発に行なわれており，とくに化 学反応を伴らガス吸収について多数の報告がなされてい る。

正田，浅井らはフルカリ水溶液による炭酸ガス，硫化 水素の吸収を液柱，濡れ壁を使って行ない，反応吸収機

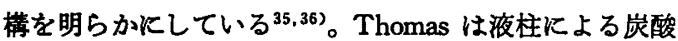
ガスのモノェタタールアミンへの吸収を行ない(81), Astarita らは濡れ壁を使って硫化水素の苛性ソーダ, フルカ リ炭酸塩括よびモノエタノールフミンへの吸収を行な い, 反応機構を明らかにしている1,2)。Brian らは需れ壁 を使って㞸酸ガスのモノェタノールフミンによる四収を ブロピレンの放散と同時に行ない，炭酸ガスの吸収によ る液境界層内の表面張力の勾配がすたらす乱れによって 物質移動㐿数か増加すること，この物質移動保数を採用 することにより浸透説による理論解との一致がよくなる ことを報告しているい。

Jefferys らは液柱により炭酸ガスの炭酸ソーダ水溶液

*昭和 44 年6月19日 受理

* Akira Suzuki f代田化工設誅式会社
への吸収を行ない，吸収液にクリシンを添加することに より吸収速度が増加することを述べている(2)。アルカリ 性水溶液による炭酸ガスの吸収において，触媒を添加す ることにより吸収速度が增加することは，すでに工業プ ロセスのいくつかに応用されている。添加する触媒とし

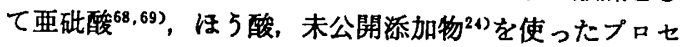
スの紹介がなされている。Danckwerts らは、フルカリ性 水溶液による岸酸ガスの吸収において，添加触媒が吸収 速度を增大せしめる機構を溶液の境界層における炭酸が スの水和反応，すなわち触媒が反応速度の遅い式 (1)の 反応を

$$
\mathrm{CO}_{2}+\mathrm{H}_{2} \mathrm{O} \rightleftarrows \mathrm{HCO}_{3}^{-}+\mathrm{H}^{+}
$$

促進することで説明している。触媒として亜碓酸，ホル ムアルデヒド，次亜塩素酸などの炭酸ガスの吸収速度へ の影箁を擋拌槽を使って測定し，触媒作用は溶液に吸収 されている炭酸ガスの量が多い状態で著しいことを報告 している11,12,72)。

Danckwerts らは炭酸ガスの硫酸ソーダ、炭酸カリ打よ び重炭酸カリの爱街溶液, 苛性ソーダ水溶液への吸収を 擋拌槽および各種充填物を充填した充填搭を使い，ガス 側の抵抗が無視できる条件で測定し，求めた液側物質移 動係数と有効表面積の値を報告している ${ }^{13,14,70) 。 ~}$

吉田らは充填塔および連珠塔を使って炭酸ガスの苛性 ソーダ, 苛性カリ水溶液への吸収を行ない有効表面積を 求めた ${ }^{11}$ 。恩田らは各種の充填物を使ってフンモニフの 水による吸収 ${ }^{61)}$ ，炭酸ガスの水による吸収 ${ }^{62)}$ ガス側，液側物質移動係数，および有効表面積を表わす 式 (2)，(3)，(4) を提案した。

$$
\begin{gathered}
\frac{k_{G} R T}{a_{t} D_{G}}=0.272\left(\frac{G}{a_{t} \mu_{G}}\right)^{0.80}\left(\frac{\rho_{G}{ }^{2} g}{\mu_{G}{ }^{2} a_{t}^{3}}\right)^{0.20} \\
\left(\frac{\mu_{G}}{\rho_{G} D_{G}}\right)^{0.50}\left(a_{t} D_{p}\right)^{-1.6} \\
k_{L}\left(\frac{\rho_{L}}{\mu_{L} g}\right)^{1 / 3}=0.015\left(\frac{L}{a_{t} \mu_{L}}\right)^{1 / 2}\left(\frac{\mu_{L}}{\rho_{L} D_{L}}\right)^{-1 / 2}\left(a_{t} D_{p}\right)^{0.4}
\end{gathered}
$$




$$
\begin{gathered}
\frac{a_{w}}{a_{t}}=1-\exp \left\{-1.45\left(\frac{L}{a_{t} \mu_{L}}\right)^{0.1}\left(\frac{a_{t} L^{2}}{\rho_{L}^{2} g}\right)^{-0.05}\right. \\
\left.\left(\frac{L^{2}}{\rho_{L} \sigma a_{t}}\right)^{0.2}\left(\frac{\sigma_{c}}{\sigma}\right)^{0.75}\right\}
\end{gathered}
$$

この物質移動係数と有効表面積とから計算した総括容 量係数は，炭酸ガスとモノェタノールアミン系で夷測し たそれと $20 \%$ 以内で一致したことを報告している。上 記の総括容量係数の計算を二次反応として計算している ことから，個々の物質移動係数，拉よび有効表面積の式 は二次反応を伴う吸収系に拈いても十分使用できると述 べている ${ }^{63)}$ 。Vivian らは炭酸ガスと水系の吸収を充填 塔で行ない液側抵抗を ${ }^{88,89)}$, Sharma らは亜硫酸ガス, 塩素と水系, アンモニア, トリェチルアミンと硫酸系の 吸収によりガス側基準容量係数を73), Ellis は炭酸ガスの アルカリおよびアミンへの吸収を充填塔で行ない総括容 量係数を ${ }^{25)}$ ，DeWaal らは炭酸ガスと水系，酸素と亜硫 酸水溶液系の吸収を充填塔で行ない液側基準容量係数 を(15)，Astarita らは炭酸ガスのアルカリ水溶液への吸収 を充填塔で行ない夜側基準容量係数る゙゙ 報告している。

Porter らは塔径 3 フィートの泡鐘塔で炭酸ガスと水打 よび苛性ソーダ水溶液による吸収を( ${ }^{66)}$, Smith らは多孔 板荅で炭酸ガスー苛性ソーダ水溶液の吸収 ${ }^{71)}$ を行ない， 液側物質移動係数と有効表面積を報告している。

吸収装磒として工業的に使用されている気液接触装置 は充填塔，濡れ壁塔，段荅，シェットその他の気液接触 装磒などで，使用目的，気液比，腐蝕雾囲気，固形物括 よび発泡性の有無などを考虑して選ばれる。

充填塔はガスの吸吸にもっとも一般的に使われている 気液接触装置である。Eckert らは多数のガス吸吸系に対 して充填塔の特性と総括容量係数の資料について述へて (る26)。Morton らはマクマホーン, スター, ラシヒリ ングの三種の充填物について運転特性を測定し，ローデ ^ング領域以下(16)とローディング領域47)における圧力損 失とホールドアップの関係式を実測値と比較している。 この関係式は充填物をサドル型とリング型の二つに区分
して与皇られて怙り，実測値との比較については18)，口 ーディング領域以下では士50\%以内，ローディング領域 では $440 \%$ 以内で一致すると報告している。 Mohunta らは充填塔におけるホールドフップの関係式を(9), Secor らはホールドフッブが化学反応を伴らガス四収の吸収速 度に与える影響を ${ }^{75)}$ 報告している。Shulman らはベル ルサドル，カーボンおよびセラミックラシヒリシグ充填

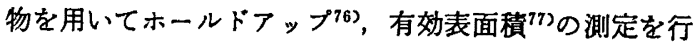
ない，ガス側物質移動係数，有効表面積とホールドアッ プとの関係を ${ }^{78)}$ ，DeWaal らは塔径 $1 フ ィ$ フのラシ ヒリング充填塔で圧力損失，ホールドフップ，有効表面

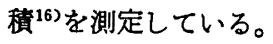

充填塔内の充填層を流れる液の分散状態が吸収の性能 に影響があることは当然であり，充填塔の設計上，液の 分散機構, 塔径と充填物寸法の関保, 充填高の影製など は重要な問題点である。充填層内の液分散のモデル，お よびその解析が Hoftyzer ${ }^{37}$, Jamson ${ }^{43)}$, Porter ${ }^{67)}$ らに よってなされている。

充填塔のフラッディソグについては周知の Sherwood, Lobo, Eckert らによる線図があるが，Mersmann は新し いフラッディングおよびローディング線図を提案し，そ の計算例をあげている ${ }^{50)}$ 。充填塔のフラッディングの計 算に必要な各種の充填物に対応するパッキングファクタ 一が Eckert らにより発表されて扣り，これを表1に示 才27)。

Danckwerts らは擋拌槽で求めた吸収速度のデータを 使って充填塔を設計する手法を発表している13,14。す なわち適当な擋拌速度を選ぶことによって擋拌槽と充 填荅で得られる物質移動を一致させることが可能てあ りしたがって擋拌槽を充填荅のモデルとして使うこ とができる。炭酸ガスの苛性ンーダ水溶液による吸収実 験の結果，十分な精度でこの手法が使用できるとしてい る。 Semmelbauer はガス吸収の速度論と流体力学とに

\begin{tabular}{|c|c|c|c|c|c|c|c|c|c|c|c|c|}
\hline \multicolumn{13}{|c|}{ 表 1} \\
\hline \multirow{2}{*}{ 充 } & 材 & & & & 呼 & & 寸 & 法 & (nch) & & & \\
\hline & & $1 / 4$ & $3 / 8$ & $1 / 2$ & $5 / 8$ & $3 / 4$ & 1 & $11 / 4$ & $11 / 2$ & 2 & 3 & $31 / 2$ \\
\hline Intalox Saddle & Ceramic & 600 & - & 200 & - & 145 & 98 & - & 52 & 40 & $22^{*}$ & - \\
\hline Intalox Saddle & Plastic & - & - & - & 一 & - & $31^{*}$ & - & - & $21^{*}$ & $14^{*}$ & - \\
\hline Berl Saddle & Ceramic & 900 & - & 240 & 一 & 170 & 110 & - & 65 & 45 & - & - \\
\hline Pall Ring & Ceramic & - & - & - & 一 & 一 & 一 & - & 一 & $44^{*}$ & $29^{*}$ & - \\
\hline Pall Ring & Plastic & - & - & 一 & 97 & 一 & 52 & - & 32 & 25 & - & 16 \\
\hline Pall Ring & Metal & - & - & - & 71 & 一 & 48 & - & 28 & 20 & - & - \\
\hline Raschig Ring & Ceramic & 1400 & 1000 & 640 & 380 & 255 & 160 & 125 & 95 & 65 & 37 & - \\
\hline Raschig Ring 1/32" $/ Z_{x}$ & Metal & 700 & 一 & 300 & 190 & 155 & 115 & - & - & 一 & 一 & - \\
\hline $\begin{array}{l}\text { Raschig Ring } 1 / 16^{\prime \prime} \text { 厚み } \\
\text { Raschig Ring } 1 / 8^{\prime \prime} \text { 厉み } \\
\text { * Iwao Engg. Co. Data }\end{array}$ & $\begin{array}{l}\text { Metal } \\
\text { Metal }\end{array}$ & - & - & $\begin{array}{r}340 \\
-\end{array}$ & $\begin{array}{r}290 \\
-\end{array}$ & $\begin{array}{r}230 \\
-\end{array}$ & $\begin{array}{r}145 \\
-\end{array}$ & $\begin{array}{r}110 \\
-\end{array}$ & $\begin{array}{l}83 \\
-\end{array}$ & $\begin{array}{l}57 \\
-\end{array}$ & $\begin{array}{l}32 \\
38\end{array}$ & 一 \\
\hline & & & & & & & & & & & & \\
\hline
\end{tabular}
るとつきH.T.U. の計算法を提案し，この手法は他の 
物質移動をともな5単位操作においてす使用可能である と述へている ${ }^{79)}$ 。泡鐘荅は従来からすっとる広く採用さ れている気液接触装置の一つであるが，その段効率5,27)， 運転籁囲 ${ }^{511}$ につての検討がなされている。多孔板塔に 関する研究は主として装置設計上の問題について行なわ れており，下降管の設計法 ${ }^{85)}$ ，压力損失の計算式 ${ }^{17,80,93), ~}$ 安定運転篹囲91などの報告がある。吉田らは長方形断面 を有する多孔板落の圧力損失, ホールドフップ, 飛洙同 伴について通常の多孔板塔との比较を行なっている ${ }^{92) 。 ~}$ Giles らはターボグリッド塔の圧力損失，トレイの夜油 れ，飛沫同伴の測定を行ない，他の段塔との比較につい て述へている34。Todd らはジェットトレイ塔について の実験から反力損失, 飛洙同伴, 安定運転範囲などの設 計資料を求め，とくに液量の多い気液接触に適するとし ている ${ }^{86)}$ 。Manning は段塔の段間にガスに遠心力を与 える機構を設けることにより，過大な飛洙同伴なしに塔 内ガス流速を大にとることができると報告している522。 濡れ壁荅のフラッディングに関する関係式が藤田により まとめられている299。

泡鐘塔, 多孔板荅、ターボグッッド荅、リップルトレ イ塔の特性についての実験が $\mathrm{Cei}^{10)}, \mathrm{McQuinn} 5^{533}$ に よって行なわれ，压力損失，効率の比较が述べられてい る。Thibodeaux らは流れ特性の面から段荅と充填塔の 比較を行ない，それらの選定の基準とついて提案してい る87)。Bauer らはベンチュリースクラパーで炭酸ガスの 水への吸収実験を行ない, 最適気液比, 安定運転範用を 求め, ベンチュリースクラバーによるガス吸収に拈いて は液流量の決定が性能および経験性に大きな影暗を与え ることを指摘している6)。

工業装置としての吸収装置の設計および運転にあたっ て, 系の腐的性, 発泡性は装置の材料扣よび型式の選定 に大きな影整を与える。Schwarz らは市販の表面活性剂 そついてその作用, 用途を紹介し，消泡剤としての利用 Кついてすふれている811。

熱炭酸カリ水溶液を使った吸收装置》，モノェタノ一 ルアミンを使った吸収装置において経験された腐蝕とそ の対策について多数の報告が発表されている $18,28,54,60,64)$

\section{2. 吸收ブロセス}

本稿では打すに酸性ガス，すなわち炭酸ガス，硫化水 素, 硫化カルボニルなどの吸収プロセスで，最近の文献 に発表されたブロセスについて紹介する。工業的に使用 されている酸性ガスの吸収除去プロセスは，フミン，炭 酸カリなどに代表される化学吸収プロセス, 酸性ガスの メタノールなどの溶郕に対する溶解性を利用した物理吸 収ファセス，吸収溶液として混合溶剤を使らことにより
化学吸収と物理吸収の両機能を発揮するプロセスなどが 発表されている。最近は装置の大型化，ガス吸収の操作 圧力の上昇の傾向から，化学吸収に比へて溶液再生熱が 少なくてすむ物理吸収が注目され，より酸性ガスの溶解 度の大きい溶剤を使用した新プロセスを開発する試みが なされているようである。

アミン水溶液に上る酸性ガスの吸収は，最近その理論 的解析る多数行なわれていることは前述したが，工業装 㯰としてのフミンブロセスの利用に関する報告す多数発 表されている。Wendt らはSNPA プロセスについて 報告している90)。このプロセスは天然ガスに大量に含ま れている硫化水素を除去するために，四収溶液としてデ タノールフミン（DEA）の水溶液を使らプロセスであ るが，通常の DEA プロセスに比較して DEA の淟度が 高く， DEA 20 30 wt \%，乙かも循環溶液あたりの硫 化水素吸収量を大きくとることにより，大幅に循環夜量 を少なくしている点に特徽がある。このため装固は小さ くてすみ, 溶液再生に必要な熱量す少ない利点がある。 モノェタノールフミン（MEA）水溶液による脱硫と比 較した場合，精製ガス中の硫化水素残は大きいか，溶液 の劣化の度合, 溶液の損失の面で優れている。実装置に おける運転の実績から，溶夜のアミン湿度の高いこと， 吸収夜に吸収される酸性ガス量の多いことから心配され る腐蝕は，通常のフミンプラントに於ける腐蝕に比へ， 特別な問題はなかったといわれる。Holderは $\beta \beta$ ヒドロ オキシアミノェチルエーテル（DGA）を吸収溶剤とし た酸性ガス除去プロセスについて，パイロットプラント および既存のモノェタノールフミンとェチレングライコ ール（MEA-DEG）のプラントの溶液の入れ換えによ って得られた結果について発表している38)。Maddoxら はMEA による炭酸ガスと硫化水素の除去について, 設 計資料扣よび設計法を述へている55,57)。工業的に使用さ れているフミン (MEA, DEA, TEA, MDEA, グライコ 一ルアミン)による脱硫プロセスに関する全般的な解説 が発表されている56,58)。

Benson らによって開発された熱炭酸カリ水溶液によ る酸性ガスの除去プロセスについては多数の稼動中の工 業装埴があり,プロセスの解説, 設計資料, 運転実縝な どに報告が行なかれている8,9,59)。このブロセスは，そ の特徵である吸収塔の運転温度が高いため, 精製がス中 の炭酸ガス残が MEA プロセス, GV プロセスに比較し て高い点に問題があったが，従来の炭酸カリ水溶液に添 加剤を加えることによって炭酸ガス残を $0.1 \%$ 以下に容 易に減すことができるようになり，すでに工業装置で確 認されている。このプロセスに捣いては, 吸收温度が高 いため，ガス中の硫化カルボニルが式 (5)によって水和 され，定量的に除去される利点がある。 


$$
\mathrm{COS}+\mathrm{H}_{2} \mathrm{O} \longrightarrow \mathrm{CO}_{2}+\mathrm{H}_{2} \mathrm{~S}
$$

添加剂を加えた熱炭酸カリプロセスを改良熱カリプロセ ス (Modified Benfield Process) と称する。炭酸カリ乐 溶液に触媒作用を有する添加物を加えることにより，酸 性ガス吸収の吸収速度, 吸収能力, 溶液上の気液平衡の 改良をはかったプロセスについては先に述べたが，その 中の一つである GV プロセス ${ }^{68,699}$ は亚砒酸を添加郕と して加えたプロセスであり，すでに多数の工業装置が稼 動中である。このブロセスは熱炭酸カリブロセスが炭酸 ガスと硫化水素の同時吸収であるのに比較し，添加肪と 硫化水素の反応により，ガス中の硫化水素と炭酸ガスの 選択的除去が可能30)である。吸収除去した硫化水素は溶 液の空気酸化により固型硫黄として回収することができ る。添加剤の種類は明らかにされていないが，カタカー ブプロセス (Catacarb Process) が，炭酸カリ水溶液に 特殊な添加物を加えることにより，従来の熱炭酸カリブ ロセスに比較して精製ガス中の炭酸ガス残，溶液再生 熱, 循環溶夜当りの炭酸ガスの吸収量などに大幅な改善 がみられ，大型フンモニア装置の炭酸ガス除去ブロセス として注目されている。すでに工業装固も稼動中であ

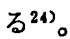

アミン，炭酸カリ水溶液による酸性ガスの除去プロセ スは化学反応を伴 5 吸収プロセスであり，溶液に曼収さ れる酸性ガス量は溶液中のアミンまたは炭酸カリ量によ って，たとえガス中の酸性ガスの分压がいかに高くと る，限界がある。一方，物理吸収に扣いては，ガス中の 酸性ガスの分圧が高ければ高いほど溶液中に吸収される 酸性ガスの量は増加する。スルフィノールプロセス (Sulfinol Process) は, ジイソプロパノールフミンとス ルホランおよび少量の水からなる混合溶液を使うことに より，酸性ガスを除去するプロセスである。溶液は化学 吸収と物理吸収の両作用を有するので両者の特徽をそな えている。すなわち，酸性ガスの吸収能が高く，溶液再 生のための熱が少なくてすみ，ガス中のメルカプタン, 硫化カルボニル，水の除去も同時に行なわれる。溶液の 腐蝕性, 損失す少ないといわれている。パイロットブラ ントおよび工業装置の解説, 運転実績等多数の報告がな されている19 23)。

酸性ガスの除去に物理夢収を利用するプロセスは古く から工業装置に採用されている。物理吸収に打いては， 溶液中に吸収される酸性ガスの量は酸性ガスの溶解度と 分化によって決定される。したがって高圧におけけがス 吸収に適している。酸性ガスを吸収した溶液の再生は， 本質的には減圧によってなされるので，溶液再生のため の熱は化学吸収の場合に比べて無視できる程度である。 物理吸収プロセスに抒いては，もちろん溶剂の安定性， 腐蝕性、ニストなどを考㤫せねばならないが，酸性ガス
に対する溶解度の大きい溶郕を使うことがすっとも重要 である。レクチゾール (Rectisol Process) はメタノール を溶剤とした酸性ガスの吸収プロセスである。酸性ガス の溶解度を增加し，溶剤損失を减少するため，吸収操作 は低温 $\left(-60^{\circ} \mathrm{C}\right)$ で行なわれる。プロセスの解説 ${ }^{39)}$ と 工業装置の紹介(6)がなされている。Kutsher らはボリェ チレングライコールのディチルェーテル (DMPEG) が 炭酸ガス，硫化水素，メルカプタンに対し，高い吸收能 を示すことからパイロットプラントの結果を報告してい る(1)。硫化水素は $1 \mathrm{ppm}$ 以下に，炭酸ガスは $0.3 \%$ 以 下に精製することが可能で, 硫化水素および硫化カルボ ニルを含むガスを脱硫し，全硫黄分 $3 \mathrm{ppm}$ 以下に精製 することができた。酸性ガスの除去ととすにガスの脱水 る同時に行なわれると述へている。溶液の発泡性, 劣化 が少なく，溶液の再生は減圧と空気によるストリ,ビン グが採用される。溶液の硫化水素之炭酸ガスの溶解度の 差を利用して両者の選択吸収も可能であり，ガス中の酸 性ガス分压が低い場合には、デインブロパノールフミン （DIPA）を溶液に添加した混合溶液を使うのが好ましい と述へている。

Stotler はアセトンを吸収剤として使用する酸性ガス 除去プロセスを発表している。その特徽は酸性ガスの溶 解度が高く，再生熱が少なく，腐蝕性が少ないなどであ る。ハイイロットブラントで得られた結果をるとにして他 のプロセスとの経済性の比較を行なって和り ${ }^{82)}$ ，精製ガ ス中の炭酸ガスは数 ppm 以下にすることが可能である が, 経済的には $100 \mathrm{ppm}$ 程度であろうと述てている。nメチルピロリドンを酸性ガスの吸收溶郕とするピューリ ゾールプロセス (Purisol Process) が高圧下のガス精製 プロセスとして注目されはじめている39,41)。さきに述へ た低温におけるメタノールを溶剤とするレクチソールフ ロセスに比へ，ガス精製の圧力が 80 気压以上ではピュ ーリゾールプロセスの方が経済的であるといわれてい る。したがって高圧天然ガス中の酸性ガスの除去, 高压 （80 120 気戍）ガス化ブロセスで発生した合成原料ガス の精製，大型水素製造装固における王縮後の脱炭酸など に使用することが可能である。このブロセスはガスの吸 収が常温で行なわれるので、レクチゾールブロセスで必 要な泠涷設備は不要である。溶剤の安定性が高い，硫化 水素と炭酸ガスの選択吸収が可能であり，硫化水素 1 ppm 以下，炭酸ガス $0.1 \%$ 以下に精製することが可能 である。

酸性ガスの除去プロセスには化学吸収, 物理吸収,お よび両者の併用のプロセスなどがあるが，使用目的，使 用条件，関連設備とのつながりなどから最適なブロセス を採用するべきである。 Riesenfeld らは天然ガスの脱硫 プロセスの最近の進歩について述へ，各プロセスの解説 
を行なっている711。Hoogen Doorn ガスはの脱硫プロセ スについて，化学吸収と物理吸収の両プロセスの比較を 行なっているいう。Fitzgerald らは酸性ガスの組成，メル カブタンの有無により酸性ガス除去ブロセスの選定の方 針を、それぞれのプロセスの使用限界，最適応用範团，
設計資料などを考虑して解説している ${ }^{31,32) 。 ~}$

煙道ガスの脱硫は近年公害問題の解決のため注目をあ つめているが，この分野に和ける研究開発の現状，ハイ ロットプラントの運転結果についていくつかの文献が発 表されている33,45,83)。

\section{使 用 犃 号}

$a_{i}:$ 充填物の全表面積 $\left[\mathrm{m}^{2} / \mathrm{m}^{3}\right], \quad a_{w}$ : 充填物の需れ面稓 $\left[\mathrm{m}^{2} / \mathrm{m}^{3}\right]$,

$D_{G}:$ 気相抁散保数 $\left[\mathrm{m}^{2} / \mathrm{hr}\right], D_{L}$ : 液相払 散牦数 $\left[\mathrm{m}^{2} / \mathrm{hr}\right], D_{\mathrm{p}}$ : 充填物の代表抾 $[\mathrm{m}], G$ : ガスの空塔質量速度 $\left[\mathrm{kg} / \mathrm{m}^{2} \cdot \mathrm{hr}\right], \quad g:$ 重力の加速度 $\left[\mathrm{m} / \mathrm{hr}^{2}\right]$, $k_{\mathfrak{g}}$ : 気相物質移動倸数 $\left[\mathrm{kg}-\mathrm{mole} / \mathrm{m}^{2} \cdot \mathrm{hr} \cdot \mathrm{atm}\right], \quad k_{L}$ : 液相物質移動保数 $[\mathrm{m} / \mathrm{hr}], \quad L:$ 液の空塔質量速度 $\left[\mathrm{kg} / \mathrm{m}^{2} \cdot \mathrm{hr}\right]$, $\mu_{G}$ : ガスの粘度 $[\mathrm{kg} / \mathrm{m} \cdot \mathrm{hr}], \quad \mu_{L}$ : 液の粘度 $[\mathrm{kg} / \mathrm{m} \cdot \mathrm{hr}], \quad \rho_{G}:$ ガスの密度 $\left[\mathrm{kg} / \mathrm{m}^{3}\right], \quad \rho_{L}:$ 液の密度 $\left[\mathrm{kg} / \mathrm{m}^{3}\right]$, $\sigma:$ 液の表面張力 $\left[\mathrm{kg} / \mathrm{hr} r^{2}\right], \quad \sigma_{c}$ : 臨界表面張力 $\left[\mathrm{kg} / \mathrm{hr}^{2}\right], \quad R:$ 気体定数 $\left[\mathrm{m}^{3} \cdot \mathrm{atm} / \mathrm{kg} \cdot \mathrm{mole} \cdot{ }^{\circ} \mathrm{K}\right], \quad T:$ 䋓対温度 $\left[{ }^{\circ} \mathrm{K}\right]$

\section{引用 文 献}

1) Astarita, G. and F. Gioia: Chem. Eng. Sci., 19, 963 (1964)

2) Astarita, G, F. Gioia and C. Balzano: ibid., 20, 1101 (1965)

3) Astarita, G.: I \& EC (Fund.), 2, 294 (1963)

4) Brian, P.L. T, J.E. Vivian and D.C. Matiatos: A. I. Ch. E. Journal, 13, 28 (1967)

5) Bakowski, S.: Brit. Chem. Eng., 8, 472 (1963)

6) Bauer, W.G., A.G. Friedrickson and H.M.Tsuchiya : $I$ \& EC (Proc. Design \& Devel.), 2, 178 (1963)

7) Bienstock, D. and J.H. Field: Corrosion, 17, 8 (1961)

8) Bacard, J.P. and B. J. Mayland: Hydrocarb. Proc., 41, No. 4, 128 (1962)

9) Benson, H. E. and J.H. Field: Petrol. Refiner, 39, 127 (1960)

10) Cei, R.P. and W.F. Furter: Can. Journal Chem. Eng., Dec., 341 (1965)

11) Danckwerts, P. V. and K.M. McNeil: Trans. Instn. Chem. Engrs, 45, T-32 (1967)

12) Danckwerts, P. V. and K.M. McNeil : Chem. Eng. Sci., 22, 925 (1967)

13) Danckwerts, P. V. and A. J. Gillhan : Trans. Instn. Chem. Eng. 44, T-42 (1966)

14) Danckwerts, P. V. and M. M. Sharma: Trans. Insn. Chem. Eng., 44, CE-244 (1966)

15) De Waal, K. J.A. and W. J. Beek: Chem. Eng. Sci., 22, 585 (1967)

16) De Waal, K. J.A. and A.C. Mameren : A. I. Ch. E. ICE Meeting Proc. Symp., 6, 60 (1965)

17) Detman, R.F.: Hydrocarb. Proc., 42, No. 8, 147 (1963)

18) Dingman, J.C., D. L. Allen and T.F. Moore: Hydrocarb. Proc., 45, No. 9, 285 (1966)

19) Deal, C. H., C. L. Dunn., E.S. Hill, et al. : Secs. N, Paper32, 6 th WPC (1963)

20) Dunn, C. L., E. R. Freitas, et al. : Oil-Gas Journal, March 16, 95 (1964)

21) Dunn, C. L., E. R. Freitas, et al. : Hydrocarb. Proc., 43, No. 3, 150 (1964)

22) Dunn, C. L., E. R. Freitas, et al. : Oil-Gas Journal, March 29, 89 (1965)

23) Dunn, C. L., E. R. Freitas, et al. : Hydrocarb. Proc., 44, No. 4, 137 (1965)

24) Eickmeyer, A. G.: Chem. Eng. Prog., 58, No. 4, 89 (1962)

25) Ellis, J. E.: Trans. Instn. Chem. Engrs, 38, 216 (1960)

26) Eckert, J. S, E. H. Foote, et al. : $I \& E C, 58$, No. 2, 41, (1967)

27) Eckert, J.S., E. H. Foote, et al. : Chem. Eng. Prog., 62, No. 1, 59 (1966)

28) Ewing, R.C. : Oil-Gas Journal, Oct. 30, 125 (1967)
29) 藤田重交：化学工学, 30, 179 (1966)

30) 福原：然料協会誌, 42, 628 (1963)

31) Fitzgerald, K. J. and J.A. Richardson: Hydrocarb. Proc., 45, No.7, 125 (1966)

32) Fitzgerald, K. J. and J.A. Richardson : Oil-Gas Journal, Oct. 24, 110 (1966)

33) Field, J. H., R. C. Kurtzrock and D. H. McCrea: Chem. Eng., 14, 158 (1967)

34) Giles, B.D. and C.E. Drgden : I \& EC (Proc. Design.), 2. 188 (1963)

35) 足田暗夫, 井俉汪か: 化学工学, 32, 278 (1968)

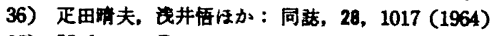

37) Hoftyzer, P. J.: Trans. Instn. Chem. Engrs., 42, T-109 (1964)

38) Holder, H. L.: Oil-Gas Journal, May 2, 83 (1966)

39) Hochgesand, G.: Chem. Jng. Techn., 40, 432 (1968)

40) Hoogen Doorn, J.C.: Trans. Instn. Chem. Engrs., 41, 264 (1963)

41) Information from Lurgi Gesellschaft fur Warme und Chemotechnik MBH.

42) Jefferys, G. V. and A.F. Bull. : Trans. Instn. Chem. Engrs., 42, $T-118$ (1964)

43) Jemson, G. J. : Trans. Instn. Chem. Engrs., 45, T-74 (1967)

44) Kutsher, G.S., G.A. Smith and P. A. Green: Oil-Gas Journal, March 20, 116 (1967)

45) Katell, S. : Chem. Eng. Płog., 62, 1067 (1966)

46) Morton, F., P. J. King and B. Atkinson: Trans. Instn. Chem. Engrs., 12, T-35 (1964)

47) Morton, F., P. J. King and B. Atkinson: ibid., 42, T-42 (1964)

48) Morton, F., P. J. King and B. Atkinson: ibid., 42, T-49 (1964)

49) Mahunta, D. M. and G.S. Laddha: Chem. Eng. Sci., 20, 1069 (1965)

50) Mersmann, A.: Chem. Ing. Techn., 37, 218 (1965)

51) Mittelstrass, M.: Chem. Tech., 10, 138 (1964)

52) Manning, E...I \& EC, 56, No.4, 14 (1964)

53) McQuinn, M. W. and W.F. Furter: Can. Jour. Chem. Eng., June, 179 (1966)

54) Moore, K. L. and D. B. Bird: Hydrocarb. Proc., 44, No. 5, 179 (1965)

55) Maddox, R. N. and M.D. Burns: Oil-Gas Journal, Sep. 18, 112 (1967)

56) Maddox, R. N. and M.D. Burns : ibid., Aug. 21, 83 (1967)

57) Maddox, R. N. and M.D. Burns : ibid., Oct. 2, 110 (1967)

58) Maddox, R. N. and M.D. Burns: ibid., Aug. 14, 131 (1967)

59) Maddox, R. N. and M. D. Burns : ibid., Nov. 13, 122 (1967) 


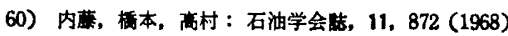

61) 恩田, 佐田, 城戸, 川竹: 化学工学, 30, 226 (1966)

62）恩田, 竹内, 小山：同哭, 31, 126 (1967)

63）恩田，苌坂，高㛢：同誌, 31, 716 (1967)

64) Oakes, B. D. and M. C. Hager: Material Protect., 5, No. 8, 25 (1966)

65) Oil-Gas Journal, May. 15, 83 (1967)

66) Porter, K.E., M.B. King and K.C. Varshney: Trans. Instn. Chem. Engrs., 44, T-274 (1966)

67) Porter, K. E. and M.C. Jones: Trans. Instn. Chem. Engrs., 41, 240 (1963)

68) Riesenfeld, F.C. and J.F. Mulloney: Petrol. Refiner, 38, No. 5, 161 (1959)

69) Riesenfeld, F.C. and C. L. Blohm: Hydrocarb. Proc., 41, No. 4, 123 (1962)

70) Richards, G. M., G. A. Ratcliff and P. V. Danckwerts : Chem. Eng. Sci., 19, 325 (1964)

71) Riesenfeld, F.C. and M. Markles: Trans. Instn. Chem. Engrs, 16, CE-240 (1968)

72) Sharma, M. M. and P. V. Danckwerts: Chem. Eng. Sci., 18, 729 (1963)

73) Sharma, M. M.: Chem. Eng. Sci., 22, 673 (1967)

74) Smith, R. K. and G. B. Wills: I \& EC (Proc. Design.), 5, 39 (1966)

75) Secor, R.M. and R.W. Southworth: A. I. Ch. E. Journal, 9, 561 (1963)

76) Shulman, H. L., C.F. Ullrich and N. Wells : ibid., 1, 247 (1955)
77) Shulman, H. L., C.F. Ulrich, A. Z. Proulxand et al. : ibid., 1. 253 (1955)

78) Shulman, H. L., C. G. Savini and R. V. Edwin: ibid., 9, 479 (1963)

79) Semmelbauer, R. : Chem. Eng. Sci., 22, 1237 (1967)

80) Sundermann, U.: Chem. Ted. (Berlin), 19, 267 (1967)

81) Schwarz, E.G. and W.G. Reid: I \& EC, 56, 26 (1964)

82) Stotler, H. H. : Hydrocarb. Proc., 42, No. 10, 154 (1963)

83) 坂部：石油学会誌, 12, No. 3, 182 (1969)

84) Thomas, W. J.: A. I. Ch. E. Journal, 12, 1051 (1966)

85) Thomas, W. J. and M. Campbell: Trans. Instn. Chem. Engrs., 45, T-64 (1967)

86) Todd, W.G. and Mauhew Van Winkle: I \& EC (Proc. Design), 6, 95 (1967)

87) Thibodeaux, L. J. and P. W. Murill : Chem. Eng., 73, No. 15, 155 (1966)

88) Vivian, J. E., P. L. T. Brian and V. J. Krukonis: A. I. Ch. E. Journal, 13, 174 (1967)

89) Vivian, J. E. : ibid., 10, 221 (1964)

90) Wendt, C. J. and L. W. Dailey: Hydrocarb. Proc., 46, No. 10, 155 (1967)

91) Yoshida, F. and Y. Miura: A. I. Ch. E. Journal, 9, 331 (1963)

92) Yoshida, F., T. Nishibe and S. Nagai : A. I. Ch. E., ICE Meeting Proc. Symp., B, 34 (1965)

93) Zelfel, E. : Chem.-Ing.-Techn., 39, 284 (1967)

94) Zelfel, E. : Chem.-Ing.-Techn., 39, 433 (1967)

[レビューおわり $]$ 